\title{
Interferon- $\gamma$ upregulates the stromelysin-1 gene expression by human skin fibroblasts in culture
}

\author{
Kyu-Suk Lee, ${ }^{1,2}$ Young-Wook Ryoo ${ }^{1}$ and \\ Joon-Young Song ${ }^{1}$ \\ 1 Department of Dermatology, Keimyung University \\ School of Medicine, Taegu 700-310, Korea \\ 2 Corresponding author \\ Accepted 7 March 1998 \\ Abbreviations: ECM, extracellular matrix; MMP, matrix metalloproteinase; IFN- $\gamma$, \\ interferon- $\gamma$; TGF- $\beta$, transforming growth factor- $\beta$; CAT, chloramphenicol acetyl \\ transferase; GAPDH, glyceraldehyde-3-phosphate dehydrogenase; TRE, tumor \\ promoter responsive element
}

\section{Introduction}

The matrix metalloproteinase (MMP)familly, which includes collagenase (MMP-1), gelatinase (MMP-2), stromelysins (MMP-3), matrilysin and metalloelastase, were structurally related zinc-dependent proteolytic enzymes, yet specific activities are divergent (Woessner, 1990; McCachren, 1991; Mauviel, 1993). Stromelysin-1 and -2 are closely related, yet distinct from metalloproteinases, and both can degrade many non-collagenous connetive tissue macromolecules such as fibronectin, laminin, elastin, IgG, and proteoglycans (Chin et al,, 1985). Stromelysin-1-producing keratinocytes resided on the basement membrane, whereas stromelysin-2-producing keratinocytes were in contact with the dermal matrix (Saarialho-Kere et al., 1993). Furthermore, stromelysin-1 expression was prominent in dermal fibroblasts, whereas no signal for stromelysin-2 was observed in any dermal cells (Saarialhokere et al., 1993). Beside participating in normal connective tissue homeostasis, development and remodeling, the proteolytic activity of matrix metalloproteinases contributes significantly to the tissue damage that occurs in chronic inflamatory disease, such as rheumatoid arthritis and osteoarthrtis (Pelletier et al., 1993), as well as tumor invasion (Martrisian, 1990).

Metalloproteinases are produced by multiple cell types and typically, their expressions are tightly regulated and limied to periods of active remodelling. The cell typespecific expression of metalloproteinases is regulated by various factors, including cell-matrix interaction, growth factors and cytokines, lipid mediator, tumor promotors, and inflammatory agent such as bacterial lipopolysaccharide (Saarialho-Kere et al., 1993). One of the cytokines previously shown to modulate the activity of MMP-1 and MMP-3 is interferon- $\gamma$ (IFN- $\gamma$ ), a physiologic mediator synthesized and released primarily by helper T-lymphocytes (Sen, 1992). It has been demonstrated that IFN- $\gamma$ decreases the activity of MMP-1 in rheumatoid synovial fibroblasts, human articular chondrocytes or human alveolar macrophages in culture (Andrew et al., 1990; Shaprio et al., 1990; Unemori et al., 1991). But the expression of MMP-1 and MMP-3 in cultured human skin keratinocytes cultures were found to be upregulated by the addition of IFN- $\gamma$. IFN- $\gamma$ also suppressed lipopoly-saccharide-induced production of srtromelysin in human macrophage, whereas inhibition of tissue inhibitor of metalloproteinase synthesis required 50 to 100 fold higher concentrations of this cytokine (Shaprio et al., 1990). Thus, these previous studies suggest that IFN- $\gamma$ affect MMP activities of a variety of different cell types in vitro culture systems. But, few
Keywords: stromelysin-1, interferon- $\gamma, \mathrm{AP}-1$, gene expression 
reports are available about the effect of this cytokine on MMP activities in skin dermal fibroblasts.

In this study, we have examined the expression of the stromelysin-1 and collagenase in cultured human dermal fibroblasts treated with IFN- $\gamma$ and/or TGF- $\beta$.

\section{Materials and methods}

\section{Cell Cultures}

The cell line used in the present experiment was established from foreskin of infant. Cells were grown in Dulbecco's modified Eagle's medium (DMEM) with 10\% fetal bovine serum, penicillin $(100 \mathrm{U} / \mathrm{ml})$, streptomycin $(100 \mu \mathrm{g} / \mathrm{ml})$, and amphotericine B $(1 \mu \mathrm{g} / \mathrm{ml})$ at $37^{\circ} \mathrm{C}$ in a humidified atmosphere of $5 \% \mathrm{CO}_{2}$. Trypan blue test was used for checking cell viability. Confluent fibroblast in 100-mm petri dishes were treated with IFN- $\gamma$ (Sigma Co., $\mathrm{MO}$ ) or TGF- $\beta$ (Genzyme Co., CA) in the concentrations indicated for $24 \mathrm{~h}$.

\section{Northern blot analysis}

Total celluar RNA was isolated by the methods of Chomzynski and Sacchi from cultured normal skin fibroblasts. An equal amount of total RNA ( $25 \mu \mathrm{g})$ was fractionated by $1 \%$ agarose gel electrophoresis (100 volts, $5 \mathrm{~h}$ ) after denaturating the samples with formaldehyde and formamide and stained with ethidium bromide (Whal et al., 1979). RNA transcripts obtained were transferred to Zeta probe filters (BioRad, Richmond, USA) by vacuum transfer and immobilized by heating at $80^{\circ} \mathrm{C}$ for $30 \mathrm{~min}$. Each filter was prehybridized for $12-18 \mathrm{~h}$ and subsequently hybridized for $24 \mathrm{~h}$ with cDNAs labeled by [ $\left.{ }^{32} \mathrm{P}\right] \mathrm{dCTP}$ (NEG 036H, New England Nuclear, Boston, USA) by nick translation (Rigby et al., 1977). Following hybridization, the filter was washed and autoradiography was performed (Thomas P., 1980). The following humansequence-specific cDNAs were utilized this study: for stromelysin-1, a 1.5-kb stromelysin cDNA (Saus et al., 1988); for collagenase, a 2.0-kb collagenase cDNA (Goldberg et al., 1986); for glyceraldehyde-3-phosphate dehydrophate dehydrogenase (GAPDH); a 1.2-kb GAPDH cDNA (Fort et al., 1985).

\section{Transient cell transfection and CAT assay}

Human foreskin fibroblasts were transfected with 10 or $20 \mu \mathrm{g}$ of construct DNA (ST-56/CAT), which contains $0.5 \mathrm{~kb}$ of 5 '-flanking DNA of stromelysin-1 gene linked to the CAT reporter gene (Buttice et al., 1991). This construct has been derived from a $560 \mathrm{bp}$ Xhol/HindIII genomic subclone that spans from position -560 to +6 of the stromelysin-1 promoter (Saus et al., 1988).

Transfection was performed with the calcium phosphate/ DNA co-precipitation method (Graham and Van der Eb, 1973), followed by a 1 min glycerol (15\%) shock. After
$40 \mathrm{~h}$ incubation with or without the IFN- $\gamma$ or TGF- $\beta$, the cells were harvested and lysed by three cycles of freezing and thawing in $100 \mu \mathrm{l}$ of $0.25 \mathrm{M}$ Tris- $\mathrm{HCl}, \mathrm{pH} 7.8$. The protein concentration of each extract was determined with a protein assay kit (Bio-Rad) and the same amount (5-10 $\mu \mathrm{g}$ per assay) of protein from each cell extract was used for parallel determinations of CAT activity using $\left[{ }^{14} \mathrm{C}\right]$ chroramphenicol as substrate (Gorman et al., 1982). The acetylated and non-acetlated forms of radioactive chloramphenicol were seperated by thin-layer chromatography and visualized by autoradiography. The enzyme activity was quantified by cutting out pieces of thin layer chromatography plates containg different forms of $\left[{ }^{14} \mathrm{C}\right]$ chroramphenicol converted to its acetlated forms, after correction for $\beta$-galactosidase activity in each as a control of transfection efficiency (Sambrook et al., 1989).

\section{Gel mobility shift assay}

Nuclear proteins were isolated from cultured skin fibroblasts incubated with or without IFN- $\gamma$ or TGF- $\beta$ for $24 \mathrm{~h}$ using a small scale preparation technique (Andrews and Faller, 1991). For DNA binding assay, a 21-bp, 5'CGCTT GATGAGTCCAGCCGGAA-3', double-stranded oligomer containing the stromelysin-1 AP-1 binding site was used. The end-labeled oligomer (total radioactivity per reaction, $5 \times 10^{4} \mathrm{cpm}$ ) was incubated with $8 \mu \mathrm{g}$ of the nuclear extract for 30 min on ice in $20 \mu \mathrm{l}$ of binding reaction buffer (12 mM HEPES, $\mathrm{pH} 7.9 ; 4 \mathrm{mM}$ Tris, $\mathrm{pH}$ 7.9; $60 \mathrm{mM} \mathrm{KCl} 11 \mathrm{mM}$ EDTA; $1 \mathrm{mM}$ dithiothreitol; $12 \%$ glycerol) in the presence of $0.2 \mu \mathrm{g}$ of poly (dl-dC), and the DNA-protein complexs were fractionated on $4 \%$ polyacrylamide gel containing $0.4 \mathrm{X}$ Tris-borate-EDTA (TBE) buffer under non-denaturing conditions, as described previously (Tamai et al., 1994). As a competitor for the binding, a hundred-fold molar excess of the same oligomer was added to the binding reaction. The oligomer-protein complexes were visualized by autoradiography by exposure of the gels to X-ray films at $-70^{\circ} \mathrm{C}$ overnight.

\section{Results}

\section{Effect of IFN- $\gamma$ and TGF- $\beta$ on stromelysin-1 mRNA expression}

The expression of the stromelysin-1 and collagenase genes was examined in cultured fibroblasts by determining the steady-state levels of mRNA by Northern analysis. The size of stromelysin-1, collagenase, and GAPDH mRNA transcripts, was $2.2 \mathrm{~kb}, 2.4 \mathrm{~kb}$, and $1.4 \mathrm{~kb}$, respec-tively (Figure $1 \mathrm{~A})$. The levels of stromelysin-1 mRNAs were $160 \pm 12.5$ densitometric abundance units (mean \pm S.E.M.) in control, $430 \pm 20.5$ units in IFN- $\gamma$ treated group, $280 \pm 18.4$ units in both IFN- $\gamma$ and TGF- $\beta$ 
A

$\begin{array}{lllll}\operatorname{INN}-\gamma\left(1 \mu_{\mathrm{L}} / \mathrm{mL}\right) & - & + & + & - \\ \mathrm{T}\left(\mathrm{i} F-\beta\left(1 \mu_{\mathrm{g}} / \mathrm{ml}\right)\right. & - & - & + & +\end{array}$

Stromelyein-1

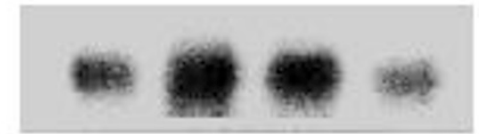

Collagenase

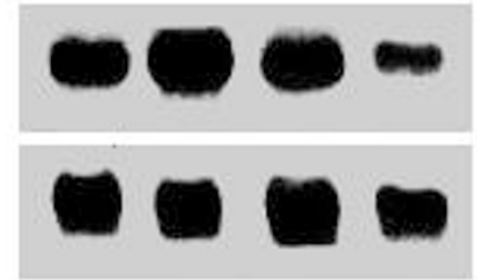

GAPIJH

\section{B}

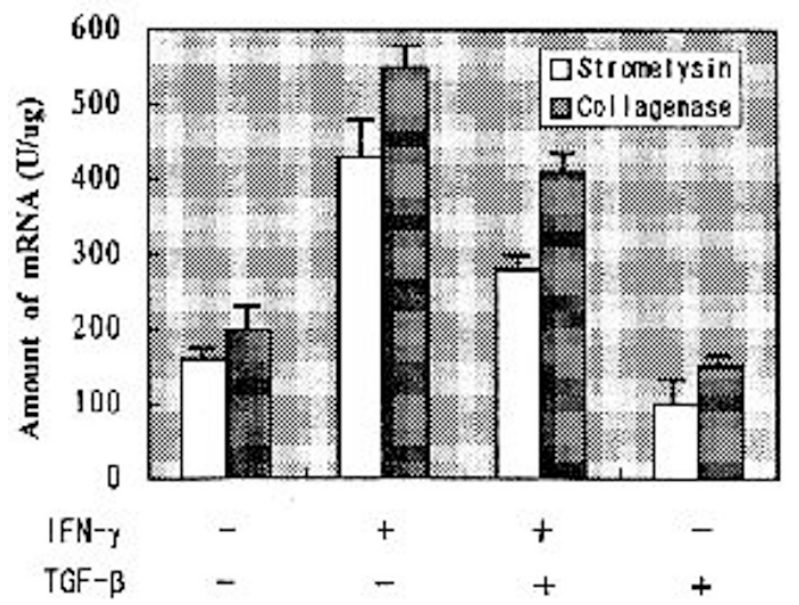

Figure 1. Effect of interferon- $\gamma$ (IFN- $\gamma$ ) and transforming growth factor- $\beta$ (TGF- $\beta$ ) on collagenase and stromelysin-1 gene expression. IFN- $\gamma$ and TGF- $\beta$, both at $1 \mu \mathrm{g} / \mathrm{ml}$, were added to confuluent fibroblast cultures maintained in medium containg $1 \%$ fetal bovine serum. Total RNA ( $15 \mu \mathrm{g} / \mathrm{lane})$ was extracted after a $24 \mathrm{~h}$ incubation and analyzed by Northern hybridization with CDNA probes for stromelysin-1, collagenase and GAPDH(A). Quantitation of stromelysin-1 and collagenase mRNA levels by densitometric scanning of the $\mathrm{X}$-ray film in A. The mRNA levels were corrected for GAPDH mRNA level in the same RNA samples Experiments were performed in triplicate and repeated twice. Bars represent mean \pm S.E.M.(B).

$(1 \mu \mathrm{g} / \mathrm{ml})$ treated, $103 \pm 8.3$ units in TGF- $\beta$ treated group. The expression of stromelysin-1 gene was significantly enhanced by IFN- $\gamma, 430 \pm 20.5$ units compared with $160 \pm 12.5$ units in control, and maximum effect was noted at $1 \mu \mathrm{g} / \mathrm{ml}$ (data not shown) and its effect was decreased by TGF- $\beta$. IFN- $\gamma$ coordinately upregulates stromelysin-1 and collagenase gene expression in cultured fibroblasts (Figure 1A and 1B).

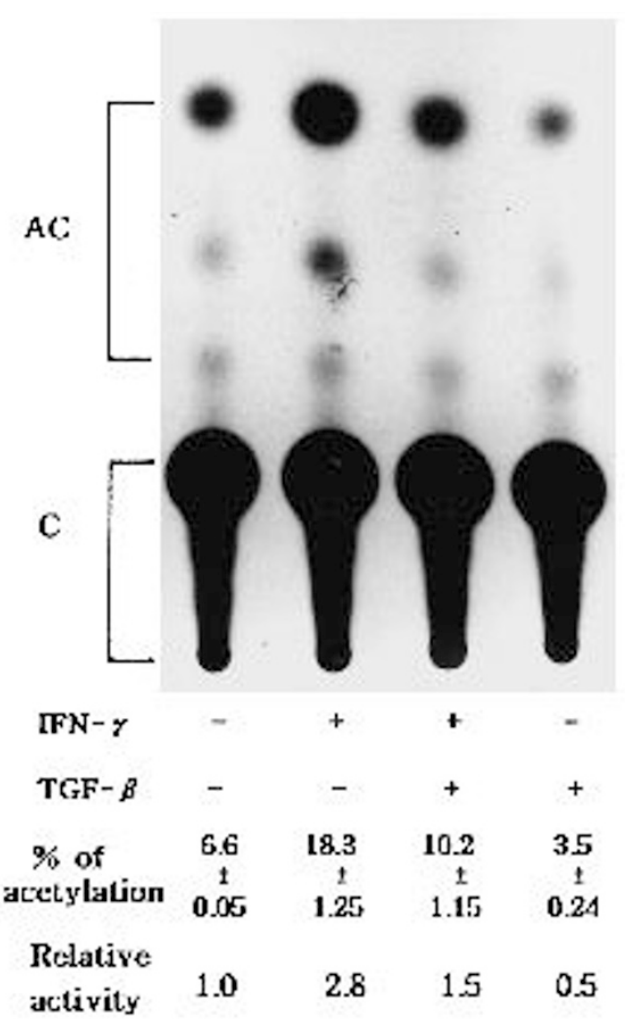

Figure 2. Enhancement of stromelysin-1 promotor activity by IFN- $\gamma$ in transient cell transfections. Confluent cultures of skin fibroblasts were transfected with the stromelysin-1 promotor/CAT gene construct ST-56/CAT. Three hours after the glycerol shock, the cells were exposed to IFN- $\gamma$ and TGF- $\beta$ in medium containg $0.5 \%$ calf serum. After 24-48 $\mathrm{h}$ of additional incubation, the cells were harvested and CAT activity was determined. CAT assay was performed by separation of acetylated (AC) and unacetylated $(\mathrm{C})$ forms of $\left[{ }^{14} \mathrm{C}\right]$ chloramphenicol by thin-layer chromatography.

\section{Tanscriptional regulation of the stromelysin-1 gene at the promoter level}

To examine the possibility that the elevated mRNA level for stromelysin-1 is resulted from enhanced transcriptional activity of the corrresponding genes, 566-bp stromelysin1 CAT constructs were used in transient transfections of cultured humam skin fibroblasts. Fifteen hours following the transfection with strmelysin-1/CAT construct, $1 \mu \mathrm{g} /$ $\mathrm{ml}$ IFN- $\gamma$ was added to parallel duplicate cultures for $24 \mathrm{~h}$. As the result of CAT assay, the percentage of acetylation were $6.6 \pm 0.05 \%$ in control group, $18.3 \pm 1.25 \%$ in IFN$\gamma$ treated group, $10.2 \pm 1.15 \%$ in both IFN- $\gamma$ and TGF- $\beta$, $3.5 \pm 0.24 \%$ in TGF- $\beta$ treated group. Therefore, the promoter activity was increased 2.8 -fold compared to untreated control (Figure 2, Table 1). IFN- $\gamma$ up-regulated stromelysin-1 promotor activity, suggesting transcriptional enhancement of gene expression, and TGF- $\beta$ antagonize 
the effect of IFN- $\gamma$.

\section{IFN- $\gamma$-treated nuclear extract leads to} increased AP-1 binding activity

Ap-1 binding activity to the [ $\left[{ }^{32} \mathrm{P}\right]$-labeled AP-1-stromelysin DNA fragment derived from the strmelysin-1 promoter was increased in IFN- $\gamma$-treated nuclear extract. The specificity of the binding was demonstrated by competetion of the binding protein with unlabeled 100 molar excess AP-1 binding element. These data empha-size the possibility of transcriptional level of regulation of stromelysin- 1 expression by interferon- $\gamma$ in cultured human skin fibro-blasts (Figure 3).

\section{Discussion}

Maintenance of the equilibrium between deposition and degradation of ECM is essential to normal tissue development and tissue repair processing. Matrix metalloproteinases form a family of enzymes capable of degrading various ECM components that are expressed in normal remodeling of connective tissue, such as that occurring during embryonic development, uterine resorption and wound healing as well as in disease states, such as in rheumatoid arthritis or tumor invasion (McCachren, 1991; Mauviel, 1993).

Stromelysin is critical for degradation of ECM of connective tissue, such as collagen III, IV and IX, fibronectin, gelatin, proteoglycans, and laminin, and for collagenase activation. These modulation of ECM is often selective and different cytokines can alter the balance between the active protease and their inhibitors (Mauviel, 1993).

It has been previously demonstrated that IFN- $\gamma$, an important lymphocyte product, is capable of inhibiting fibroblast collagen synthesis in vitro and that IFN- $\gamma$ is the most potent inhibitor among other lymphokines (Jimenez et al., 1984). It was shown that inhibitory effects of IFN- $\gamma$ on collagen synthesis were accompanied by decreased levels of type I, II and III procollagen mRNA in dermal and synovial fibroblasts (Unemori et al., 1991) and articular and costal chondrocytes (Adrew et al., 1990). Similary, the expression of MMP-3 (stromelysin) in fibroblasts cultures was found to be inhibited by the addition of IFN$\gamma$ (Mauviel et al., 1993). These results suggests that INF$\gamma$ may play an important role in preventing excessive connective tissue degradation in physiologic condition. But, these findings are not consistent with other report that IFN- $\gamma$ upregulates the expression of the collagenase and stormelysin in cultured skin keratinocytes (Tamai et al., 1995). This report further emphasizes the cell-type specificity with respect to IFN- $\gamma$ effects on the regulation of MMPs. TGF- $\beta$ showed little effect on the expression of stromelysin gene, whereas it suppressed the collagenase activity in cultured fibroblasts (Mauviel et al., 1993).

In this study, we examined the effects of IFN- $\gamma$ and/or TGF- $\beta$ on stromelysin-1 gene transcription in cultured

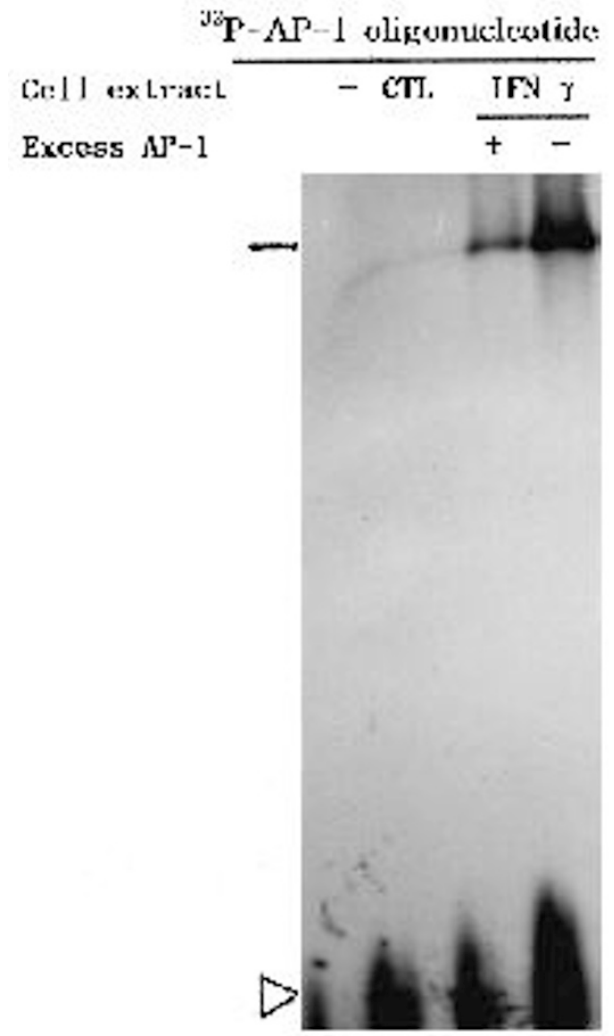

Figure 3. IFN- $\gamma$ enhances nuclear protein binding to the collagenase/stromelysin-1 AP1 cis-elements, as analyzed by gel mobility shift assay. A radioactively labeled doublestranded oligonucleotide containing the AP-1 binding sequence, was incubated with nuclear extracts from foreskin fibroblasts treated with or without IFN- $\gamma$ for $5 \mathrm{~h}$ in medium containg $10 \% \mathrm{FCS}$. The reaction mixture was subsequently fractionated by electrophoresis on $4 \%$ non-denaturing polyacrylamide gels. Competition assay was performed with a hundred-fold molar excess of unlabeled AP-1-containg oligonucleotide. CTL: control.

foreskin fibroblasts. It was revealed on Northern blot analysis that IFN- $\gamma$ increased the gene expression of stromelysin- 1 up to 2.5 fold, while TGF- $\beta$ counteracted the effect of IFN- $\gamma$. The regulation point of stromelysin-1 gene expression by IFN- $\gamma$ and TGF- $\beta$ appeared to be at the transcriptional stage. CAT assay after transient transfection of stromelysin-promoter/CAT gene construct showed that the CAT activity was enhanced by 2.8 -fold in the presence of IFN- $\gamma$ and decreased by 1.5 -fold with TGF- $\beta$. This suggests that IFN- $\gamma$ may be an up-regulator of stromelysin-1 promoter activity and TGF- $\beta$ antagonize the effect of IFN- $\gamma$.

The promoter regions of the gene encoding for stromelysin-1 have been sequenced and exhibit common features important for transcriptional regulation (Qui et al., 1989). The promoter contain a TATA box, about 30 nucleotides upstream from the transcriptional start site, 
a tumor promotor-responsive element (TRE) (Angel et al., 1987). The TRE (5'-TGAGTCA-3') binds the transcriptional factor AP-1, composed of dimers of protein product encoded by the families of oncogenes, fos and jun. In this context, it was of interest to note that the constitutive expression of stromelysin-1 has been suggested to involve AP-1. In this study, the binding activity of nuclear extract to oligonucleotide containing AP-1 sequence was increased during incubation of the dermal fibroblasts treated with IFN- $\gamma$. The competition assay was performed with 100-fold molar excess of unlabeled AP-1 containing oligonucelotide.

These data suggest that IFN- $\gamma$ may be an up-regulator of the stromelysin-1 gene expression at the level of transcriptionin human skin fibroblasts and further provide intriguing evidence for the role of the cytokine net work in regulating the extracellular matrix turnover in physiological and pathological situations.

\section{Acknowledgement}

This studies were supplemented in part by the Special Research Fund(1995) of the Dongsan Medical Center.

\section{References}

Andrew, H. Bunning, R. Plumpton, T. Clark, I. Russell, R. and Cawston, T. (1990) Inhibition of interleukin-1 induced collagenase production in human articular chondrocytes in vitro by recombinant human interferon-gamma. Arthritis Rheum. 33: 1733-1739

Andrew, N. C. and Faller, D. V. (1991) A rapid micropreparation technique for extraction of DNA-binding proteins from limiting numbers of mammalian cells. Nucleic Acids Res. 19: 2499

Angel, P. Baumann, I. Stein, B. Delius, H. and Rahmsdorf, H. (1987) TPA induction of the human collagenase gene is mediated by an inducible enhancer element located in the 5'-flanking region. Mol. Cell. Biol. 7: 2256-2266

Buttice, G. Quinones, S. and Kurkinen, M.(1991) The AP-1 site is required for basal expression but is not necessary for TPA-response of the human stromelysin gene. Nucleic Acids Res. 19: 3723-3731

Chin, J. R. Murphy, G. and Werb, Z. (1985) Stromelysin, a connective tissye degrading metalloproteinase secreted by stimulated rabbit synoial fibroblasts in parallel with collagenase. J. Biol. Chem. 260: 12367-12376

Chomczynski, P. and Sacchi, N. (1987) Single-step method of RNA isolation by acid guanidilm, thiocyanate-phenolchloroform extraction. Anal. Biochem. 162: 156-159

Fort, P. Marty, L. Piechaczyk, M. Sabrouty, S. E. I. Dan, D. Jeanteur, P. and Blanchard, J. (1985) Various rat adult tissues express only one major mRNA species from the glyceraldehyde-3-phosphate-dehydrogenase multigenic family. Natl. Acids. Res. 13: 1431-1442

Goldberg, G. I., Wilhelm, S. M., Kronberger, A. Bauer, E. A. Grant, G. A. and Eisen A. Z. (1986) Human fibroblas collagenase. Complete primary structure and homology to oncogene transfoemation-induced rat protein. J. Biol. Chem. 261: 6600-6605

Gorman, C. Moffat, L. and Howard, B. (1982) Recombinant genomes which express chloramphenicol acethyltransferase in mammalian cells. Mol. Cell Biol. 2: 1044-1054

Graham, F. and Van der Eb (1973) A new technique for the assay of infectivity of human adenovirus 5 DNA. Virology 57: 456-467
Jimenez, S. Freundhch, B. and Rosenbloom, J. (1984) Selective inhibition of diploid fibroblasts collagen synthesis by interferons. J. Clin. Invest. 74: 1116-1121

Martrisian, L. (1990) Metalloproteinases and their inhibitors in connective remodelling. Trens. Genet. 6: 121-125

Mauviel, A. (1993) Cytokine regulation of metalloproteinase gene expres-sion. J. Cell Biochem. 53: 288-295

Mauviel, A. Chen, Y. Dong, W. Evans, C. and Uitto, J. (1993) Transcrip-tional interaction of transforming growth factor- $\beta$ with proinflammatory cytokines. Current Biol. 3: $822-831$

McCachren, S. S. (1991) Expression of metalloproteinases and metal-loproteinase inhibitor in human arthritic synovium. Arthritis Rheum. 43: 1085-1093

Pelletier, J. Faure, M. Dibattista, J. Wilhelm, S. Visco, D. and Martel, P. (1993) Coordinate synthesis of sromelysin, IL-1 and oncogene protein in expremental osteoarthritis. Am. J. Patho. 146: 95-105

Quinones, S. Saus, J. Otani, Y. Harris, E.D. and Kurkinen, M.(1989) Transcriptional regulation of human stromelysin. J. Biol. Chem. 264: 8339-8334

Rigby, P. Dieckmann, M. Rhodes, C. and Berg, P. (1977) Labeling deoxyribonucleic acid to high specific in vitro by nick-translation with DNA polymerase. J. Mol. Biol. 113: 237-251

Saarialho-Kere, U. K. Pentland, A. P. Birkedal-Hansen, H. Parks, W. C. and Welgus, H. G. (1993) Distinct populations of basal keratinocytes express stromelysin-1 and stromelysin-2 in chronic wounds. J. Clin. Invest. 94: 79-88

Sambrook, J. Maniatis, T. and Fritsch, E. F. (1989) Molecular cloning In Laboratory Mannual, 2nd Edn., pp. 8.1-8.13, Cold Spring Harbor Labo-ratory, Cold Spring Harbor

Saus, J. Quinones, S. Otani, Nagase, H. Harris, E.D. Jr. and Kurkinen, M. (1988) The complete primary structure of human matrix metallo-proteinase-3. Identity with stromelysin. J. Biol. Chem. 263: 6742-6745

Sen, G. (1992) The interferon system: A bird's eye view of its biochemistry. J. Biol. Chem. 267: $5017-5020$

Shaprio, S. Campbell, E. Kobayashi, D. and Welgus, H. (1990) Immune modulation of metalloproteinase production in human macrophage: selective pretranslational suppression of intersitial collagenase and stromelysin biosynthesis by interferon- $\gamma$. J. Clin. Invest. 86: 1204-1210

Tamai, K. Ishikawa, H. Mauviel, A. and Uitto, J.(1995) Interferon- $\gamma$ coordiantely upregulate matrix metalloproteinase (MMP)-1 and MMP-3, but not tissue inhibitor of metalloproteinase (TIMP), expression in cultured keratinocytes. J. Invest. Dermatol. 104: $384-390$

Tamai K, Li K, and Uitto J (1994) Identification of a DNA-binding protein (keratinocyte transcriptitonal protein-1) recognizing a keratinocyte-specific regulatory element in the 230-kDa bullous pemphigoid antigen gene. J. Biol. Chem. 269: 493-502

Thomas, P. (1980) Hybridization of denatured RNA and small DNA fragments transferred to nitrocellulose. Proc. Natl. Sci. USA 77: 5201-5205

Unemori, E. Bair, M. Bauer, E. and Amento, E. (1991) Stromenysin expression regulates collagenase activation in human fibriblasts. J. Biol. Chem. 266: 23477-23482

Whal, G. Starn, M. and Starck, G. (1979) Efficient transfer of large DNA fragments from agarose gel to diabenzylloxymethyl paper and rapid hybridization by using dextran sulfate. Proc. Natl. Sci. USA 76: 3683-3687

Woessner, J. F. Jr. (1990) Matrix metalloproteinases and their inhibitors in connective remodelling. FASEB J. 5: 2145-2154 
